2006 ERSD Annual Report

DOE-BER Environmental Remediation Sciences Project \#1022202

\title{
Sources, Speciation and Mobility of Plutonium and Other Transuranics in the Groundwater at the Savannah River Site (Sept. 2003-Sept. 2006)
}

\author{
PI: S. Petersen ${ }^{1}$ \\ Co-PIs: K.O. Buesseler ${ }^{2}$, M. Dai ${ }^{2}$, and D. Kaplan ${ }^{3}$ \\ Pacific Northwest National Laboratory, Richland, $W^{1}$ \\ Woods Hole Oceanographic Institution ${ }^{2}$ \\ Savannah River National Laboratory ${ }^{3}$
}

\section{RESEARCH OBJECTIVES}

The intent of this research effort is to: i) provide the basis for accurate modeling and prediction of actinide transport; ii) allow for remediation strategies to be planned that might use in-situ manipulations of geochemical variables to enhance (for extraction) or retard (for immobilization) Pu mobility in the groundwater zone; iii) identify specific $\mathrm{Pu}$ sources and the extent of far field, or long-term migration of transuranics in groundwater; iv) reduce costly uncertainty in performance and risk assessment calculations. This new knowledge is essential to ensure continued public and worker safety at the DOE sites and the efficient management of cleanup and containment strategies.

\section{RESEARCH PROGRESS and IMPLICATIONS}

The following is a summary our findings as of year 3 of a 3 year project. Specific objectives of this project are: (1) the determination of the speciation of plutonium and other transuaranics $(\mathrm{Am}, \mathrm{Cm}$ ) in groundwater at the F area of the Savannah River Site. This includes the separation of Pu into particulate, colloidal and $<1$ kilo-Dalton dissolved phases and the determination of redox states and isotopic composition in each fraction; and (2) conduct laboratory tests using site-specific sediment and groundwater to compare plutonium and curium sorption (e.g., cation exchange, surface complexation, and precipitation) and derived sorption mechanism constants.

Ground water Pu data from our most recent field sampling in October 2004 can now be compared to the same four wells sampled in April 1998 and reported in Dai et al. 2002. The wells included what we consider a "background" well FSB-108D (Well 1 in Dai et al. 2002), and a sequence of wells starting at the F-area seepage basins and running downgradient towards Fourmile Branch Steam (FSB-92D, FSB-78 and FSB-79, or 2, 3, 4 , respectively).

Focusing first on the isotope ${ }^{239} \mathrm{Pu}$ and the most basic measurement of $\mathrm{Pu}$ concentration in the filtrate (that which passes through a $0.2 \mu \mathrm{m}$ filter- Fig. 2), we find in both 2004 and $1998{ }^{239} \mathrm{Pu}$ is highest near the source well $2\left(140-170 \times 10^{6}\right.$ atoms $\left./ \mathrm{kg}\right)$ and decreases rapidly in the downstream wells $3 \& 4$ (distance $=0.2$ and $0.5 \mathrm{~km}$, respectively). The background well has a measurable ${ }^{239} \mathrm{Pu}$ concentration of only 0.14 and $0.22 \times 10^{6}$ atoms $/ \mathrm{kg}$ in 1998 and 2004, respectively. Analytical errors on this measurement are quite small, and thus one conclusion is that this pattern of sharp ${ }^{239} \mathrm{Pu}$ concentration decrease with distance from the source has not changed significantly for ${ }^{239} \mathrm{Pu}$. However, there are more subtle but measurable increases in ${ }^{239} \mathrm{Pu}\left(170\right.$ vs. $140 \times 10^{6}$ atoms $/ \mathrm{kg}$ in 2004 vs. 
1998 in well 2, and 10 vs. 5, in 2004 and 1998 in well 3 and a small decrease in ${ }^{239} \mathrm{Pu}$ in well 4 ( 1 vs. 4 × $10^{6}$ atoms $/ \mathrm{kg}$ in 2004 and 1998), which is immediately downstream from an area that has been treated as a remediation step with $\mathrm{NaOH}$ to raise $\mathrm{pH}$ from 4 to 6 .

The largest difference in ${ }^{239} \mathrm{Pu}$ we see is not in concentration, but in the $\%$ reduced ${ }^{239} \mathrm{Pu}$ in 2004 over 1998. Reduced fractions of the filtrate ${ }^{239} \mathrm{Pu}$ are higher in 2004 , though we see the same overall pattern in that well 3 is always the most reducing, followed by the treated well 4. This means that the dominant geochemical form of $\mathrm{Pu}$ has shifted dramatically between years and between wells, from more oxidized $\mathrm{Pu}(\mathrm{V})$ or $\mathrm{Pu}(\mathrm{VI})$ forms in wells 1 \& $2(\mathrm{Pu}(\mathrm{V})$ is most likely (Rai et al., 1980; Choppin and Kobashi 1990; Morse and Choppin 1986)), to essentially 100\% reduced in well 3 in 2004 and 60\% reduced in well 4 (reduced forms $\mathrm{Pu}(\mathrm{III})$ and $\mathrm{Pu}(\mathrm{IV})$, most likely form is $\mathrm{Pu}(\mathrm{IV})$ (Morse and Choppin 1986; Kaplan et al. 2004)).

With this increase in \% reduced $\mathrm{Pu}$ downstream and in 2004 in general, we also measured an increase in the fraction of ${ }^{239} \mathrm{Pu}$ associated with colloids. Under more oxidizing conditions in 1998 we concluded that this fraction was small, $<5 \%$ of the total, though still measurably higher in wells $3 \& 4$. In 2004, with the shift to more reducing conditions, we see close to $20 \%$ colloidal ${ }^{239} \mathrm{Pu}$ in both wells $3 \& 4$. In sum, we have a strong decrease in ${ }^{239} \mathrm{Pu}$ concentration downstream from the source, along with a shift to more reduced forms and higher colloid associations. Batch sorption tests in the laboratory showed reduced $\mathrm{Pu}(\mathrm{IV})$ had $\mathrm{Kd}$ values 2 orders of magnitude greater than $\mathrm{Pu}(\mathrm{V})$ for these sediments (unpublished results).

${ }^{240} \mathrm{Pu}$ has a vastly different concentration pattern and greater change in 2004 vs. 1998. We have postulated (Dai et al., 2002) that the pattern of ${ }^{240} \mathrm{Pu}$ observed in 1998 was determined by the ingrowth of ${ }^{240} \mathrm{Pu}$ from ${ }^{244} \mathrm{Cm}$ decay, which we suggested was highest in well 4. $\mathrm{Cm}$ is expected to be significantly more mobile in groundwater than $\mathrm{Pu}$, based upon its lower $\mathrm{Kd}$, or affinity for particle surfaces. ${ }^{244} \mathrm{Cm}$ was produced at SRS and other sites for experimental programs for use as a heat source for isotopic electrical power generators (Stoddard, 1964), and by 1968 approximately $5 \mathrm{~kg}$ had been recovered at SRS. In 1998, we estimated groundwater ${ }^{244} \mathrm{Cm}$ as high as $2500 \times 10^{6}$ atoms $/ \mathrm{kg}$ in well 4 , thus 2-3 orders of magnitude higher than $\mathrm{Pu}$ in that well. With an 18 year half-life and several decades since its release, it has the ability to serve as a primary ${ }^{240} \mathrm{Pu}$ source in SRS groundwater $\left({ }^{243} \mathrm{Cm}\right.$ was also released, but at much lower levels that are insignificant for ${ }^{239} \mathrm{Pu}$ concentrations here). In 1998 , we estimated that $99.5 \%$ of the ${ }^{240} \mathrm{Pu}$ in well 4 originated from the decay of ${ }^{244} \mathrm{Cm}$, rather than from direct transport of ${ }^{240} \mathrm{Pu}$ in groundwater (Dai et al., 2002).

One of the goals of this current project, to measure ${ }^{244} \mathrm{Cm}$ directly, has produced an exciting new data that show agreement between what we deduced as the F-area groundwater ${ }^{244} \mathrm{Cm}$ source activity from ingrowth (Dai et al., 2002), and that measured in 2006 by both TIMS and alpha-based methods. These new analyses on 2004 samples allows us to explain the sharp drop in ${ }^{240} \mathrm{Pu}$, as being due to a large decrease in ${ }^{244} \mathrm{Cm}$, especially in the treated well 4 (was $>2500 \times 10^{6}$ atoms $/ \mathrm{kg}$, now 12). Also immediately evident in our results, is the isotope specific difference in $\mathrm{Pu}$ speciation, since the fraction of reduced ${ }^{240} \mathrm{Pu}$ is much lower than for ${ }^{239} \mathrm{Pu}$ in every well. Likewise, the percentage of 
${ }^{240} \mathrm{Pu}$ associated with colloids is correspondingly smaller, though still detectable in the downstream wells $3 \& 4$.

Why is there this source dependent $\mathrm{Pu}$ isotope difference not only in concentration, but in $\mathrm{Pu}$ speciation? We contend and ${ }^{240} \mathrm{Pu} /{ }^{239} \mathrm{Pu}$ data confirm, that $\mathrm{Pu}$ produced from ${ }^{244} \mathrm{Cm}$ decay is significantly more oxidized, which we attributed to the production of ${ }^{240} \mathrm{Pu}$ via an electron stripping Szilard-Chalmers process (Dai et al. 2002). The best evidence of this preferential formation and stabilization of the ${ }^{240} \mathrm{Pu}$ in the oxidized forms is seen in isotope data from separated oxidized and reduced $\mathrm{Pu}$ fractions. In 2004 the reduced form of $\mathrm{Pu}$ has a ${ }^{240} \mathrm{Pu} /{ }^{239} \mathrm{Pu}$ ratio of $0.05-0.06$ (wells $1 \& 2$ in 2004 ) to 0.15 (wells $3 \& 4$ in 2004). Weapons grade $\mathrm{Pu}$ is characterized by a low ${ }^{240} \mathrm{Pu}$ content, with ${ }^{240} \mathrm{Pu} /{ }^{239} \mathrm{Pu}$ ratios usually $<0.07$ (Oughton et al., 2000). Average SRS materials have ratios $<0.05$ to 0.15 , related to weapons production and reactor operations, while global fallout from weapons testing has a very constant ratio near 0.18 in soils (Krey et al., 1976; Kelley et al., 1999). Unusually high ${ }^{240} \mathrm{Pu} /{ }^{239} \mathrm{Pu}$ ratios $>1$ and as high as 10 in Wells $3 \& 4$ are specific to the oxidized fraction. Clearly this indicates a source that is specific to the enrichment of ${ }^{240} \mathrm{Pu}$ in more oxidized form.

Plutonium sorption is controlled largely by solubility, as opposed to surface complexation, adsorption or absorption (Kaplan et al. 2006b). Shown in Figure 1 is the amount of $\mathrm{Pu}$ desorbed from two sets of samples of varying $\mathrm{pH}$. The first sample was a well characterized $\mathrm{Pu}(\mathrm{V}) / \mathrm{PuO}_{2}(\mathrm{am})$ sample in contact with $0.4 \mathrm{M} \mathrm{NaClO}_{4}$. The second sample was a subsurface SRS sediment from the lysimeter study that had been in contact with $\mathrm{Pu}$ for 24 years. Aqueous $\mathrm{Pu}$ concentrations were on average 3.4 orders-ofmagnitude less than the solubility values reported by Rai et al. (2001). The lower Pu concentrations in the sediment data could be attributed to the sediment surfaces adsorbing/complexing dissolved $\mathrm{Pu}$, in addition to $\mathrm{Pu}$ dissolution occurring, or to the $\mathrm{Pu}$ solid phase being more crystalline in nature (and thus less soluble) than that studied by Rai et al. (2001).

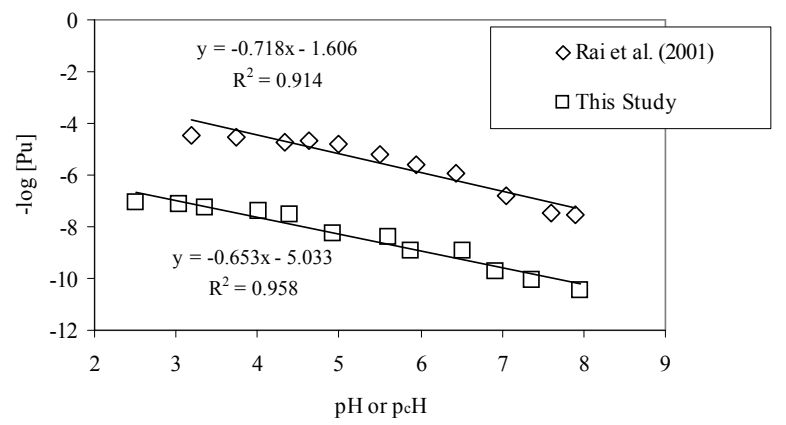

Figure 1. Comparison of sediment desorption data (this study) and a $\mathrm{Pu}(\mathrm{V}) / \mathrm{PuO}_{2}$ (am) $0.4 \mathrm{M} \mathrm{NaClO}_{4}$ system (no sediment present, $0.0018-\mu m$ filtrates); Rai et al. (2001), Kaplan et al. (2006).

The other important process governing Pu solubilization and desolubilization was redox. This is well known to influence $\mathrm{Pu}$ chemistry; however, there are no reported rates of $\mathrm{Pu}$ oxidation in sediment in the literature. An established solvent extraction, ultrafiltration technique (Kenney-Kennicutt and Morse 1985) was modified (Powell et al. 2004) so that we could determine $\mathrm{Pu}$ oxidation states in both the solid and aqueous phase at environmental $\mathrm{Pu}$ concentrations. In this experiment, $\mathrm{Pu}(\mathrm{V})$ was added to a SRS sediment and within 24 hours, $92 \%$ of it had converted to $\mathrm{Pu}(\mathrm{IV})$ (Figure 2). Oxidation 
experiments revealed that $\mathrm{Pu}$ oxidation was five orders-of-magnitude slower than the reduction rate. In fact, transport modeling of the 11-year old lysimeter sediments (Figure 10 ) indicated that $\mathrm{Pu}$ remained in the oxidized state for only $\sim 0.01 \%$ of the time. The remainder of the time it existed primarily as $\mathrm{Pu}(\mathrm{IV})$. $\mathrm{Pu}$ oxidation state distribution in the sediment of the lysimeter after 24 years of equilibrating was $\mathrm{Pu}(\mathrm{III})=0.0 \pm 0.0 \%, \mathrm{Pu}(\mathrm{IV})$ $=98.3 \%, \mathrm{Pu}(\mathrm{V})=0.02 \pm 0.03 \%$, and $\mathrm{Pu}(\mathrm{VI})=0.09 \pm 0.05 \%$.

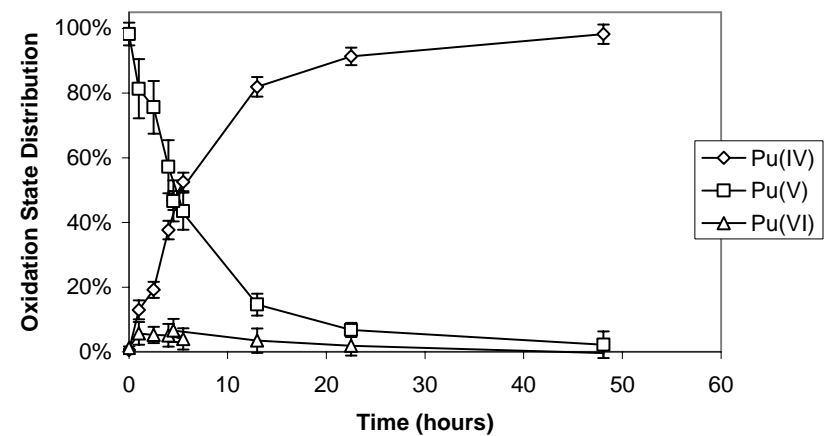

Figure 2. Oxidation state of sediment $\mathrm{Pu}$ following aqueous $\mathrm{Pu}(\mathrm{V})$ addition to lysimeter sediment suspensions (suspended solids $=$ $25,000 \mathrm{mg} \mathrm{L}^{-1}$; background electrolyte $=0.02$ $\mathrm{M} \mathrm{NaCl}$; mean and standard deviation of 2 replicates) (Kaplan et al. 2004).

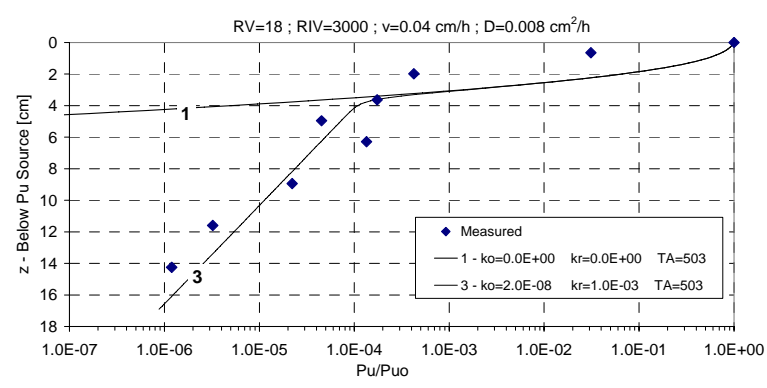

Figure 2. Normalized total Pu sediment concentrations $\left(\mathrm{Pu} / \mathrm{Pu}_{\mathrm{o}}\right)$ in the $\mathrm{Pu}^{\mathrm{IV}}\left(\mathrm{NO}_{3}\right)_{4}$ amended lysimeter. Diamonds represent measured values. Simulation input values ( $k o$ and $k r$ are the first-order rate constants for $\mathrm{Pu}(\mathrm{IV})$ oxidation and $\mathrm{Pu}(\mathrm{V} / \mathrm{VI})$ reduction, respectively): (1) sorption only; (3) with sorption and oxidation and reduction kinetics.

Using a steady state, unsaturated flow model, the importance of using a coupled model, as compared to a simple sorption model is demonstrated using the 11-year lysimeter data (Figure 3). The coupled model fits the data quite well, catching the "knee" inflection of the data. The sorption-only simulation does not capture the magnitude or the shape of the data set. By not taking into consideration the oxidation of $\mathrm{Pu}(\mathrm{IV})$, the sorption-only model underestimated transport by $350 \%$. From a practical point of view, this sorptiononly model would underestimate the actual threat posed by the $\mathrm{Pu}$, thereby biasing the calculations in the wrong direction for long term stewardship or remediation.

\section{PLANNED ACTIVITIES}

We are currently in a no-cost extension period until March 2007. We requested this extension in order to be able to: 1. participate in the October 2006 ERSP workshop at Oak Ridge; 2. allow PNNL more time to complete remaining Pu isotope analyses from 2004 field sampling; 3. allow time at WHOI to complete $244 \mathrm{Cm}$ analyses (now being done via alpha counting and not PNNL TIMS); 4. final work up of data and preparation of publications from this project. We fully expect to be able to complete this proposed work within the original budget and this extension period, and hope to build upon these studies .

\section{INFORMATION ACCESS}

Results from this ERSP project can be found at: http://cafethorium.whoi.edu and in the following publications and reports: 


\section{Presentations}

Department of Energy's Environmental Remediation Sciences Program (ERSP) Fall PI meeting, 2006. Oak Ridge Institute for Science and Education (ORISE) Oak Ridge, TN.

Journal Articles - published

Dai M.H., K.O. Buesseler and S.M. Pike. (2005) Plutonium in the groundwater at the DOE Hanford Site. Journal of Contamination Hydrology,76, 167-189.

Kaplan, D.I., D.I. Demirkanli, L. Gumapas, B.A. Powell, R.A. Fjeld, F.J. Molz and S.M. Serkiz (2006) Eleven-Year Field Study of Pu Migration from Pu III, IV, and VI Sources, Environmental Science and Technology, 40 (2), 443-448.

Powell, B.A., M.C. Duff, D.I. Kaplan, R.A. Fjeld, M. Newville, D.B. Hunter, P.M. Bertsch, J.T. Coates, P. Eng, M.L. Rivers, S.M. Serkiz, S.R. Sutton, I.R. Triay and D.T. Vaniman (2006) Plutonium Oxidation and Subsequent Reduction by Mn(IV) Minerals in Yucca Mountain Tuff, Environmental Science and Technology, 40 (11), 3508-3514.

Powell, B.A., R.A. Fjeld, D.I. Kaplan, J.T. Coates and S.M. Serkiz (2005) Pu(V)O $\mathrm{O}_{2}+$ Adsorption and Reduction by Synthetic Hematite $\left(\alpha-\mathrm{Fe}_{2} \mathrm{O}_{3}\right)$ and Goethite $(\alpha-\mathrm{FeOOH})$, Environmental Science and Technology, 39, 2107-2114.

Journal Articles - in press, submitted and in preparation

Kaplan, D. I., B. A. Powell, L. Gumapas, J. T. Gumapas, J. T. Coates, and R. A. Fjeld (2006) Influence of $\mathrm{pH}$ on Plutonium desorption /Solubilization from Sediment. Environmental Science and Technology, (accepted).

Kaplan, D.I., M. A. Duff, B.A. Powell, D.I. Demirkanli, R.A. Fjeld, and F.J. Molz. (2006) Solid Phase Plutonium Solubility and Oxidation State Transpsformations in Vadose Zone Sediments, Environmental Science and Technology (submitted).

Demirkanli, D. I., F. J. Molz, D. I. Kaplan, R. A. Fjeld, and S. M. Serkiz (2006) LongTerm Vadose Zone Plutonium Transport at the Savannah River National Laboratory, Vadose Zone Journal, (in review).

Hassellöv, M., K.O. Buesseler, S.M. Pike and M. Dai (2006) Application of cross flow ultrafiltration for the determination of colloidal abundances in suboxic ferrous-rich ground waters, Science of the Total Environment, (in press).

Seaman, J.C., P. M. Bertsch, and D. I. Kaplan. (2006). Colloid Dispersion as a Function of Recharge Injection Rate within the Atlantic Coastal Plan Sediments Underlying the SRS. Vadose Zone Journal (in review).

Filella, M., E. Balnois, K.O. Buesseler, M. Dai, M. Hassellöv, F. von der Kammer, J.L. Loizeau, D. Perret, T. Schäfer, C. Walther. (2006) Particle size distributions in water samples: A practical guide to pre-fractionation and fractionation techniques, Water Research, (in preparation) http://www.unige.ch/cabe/filella/SizeColl/WR-PSDfrac1.doc (password available upon request). 